4

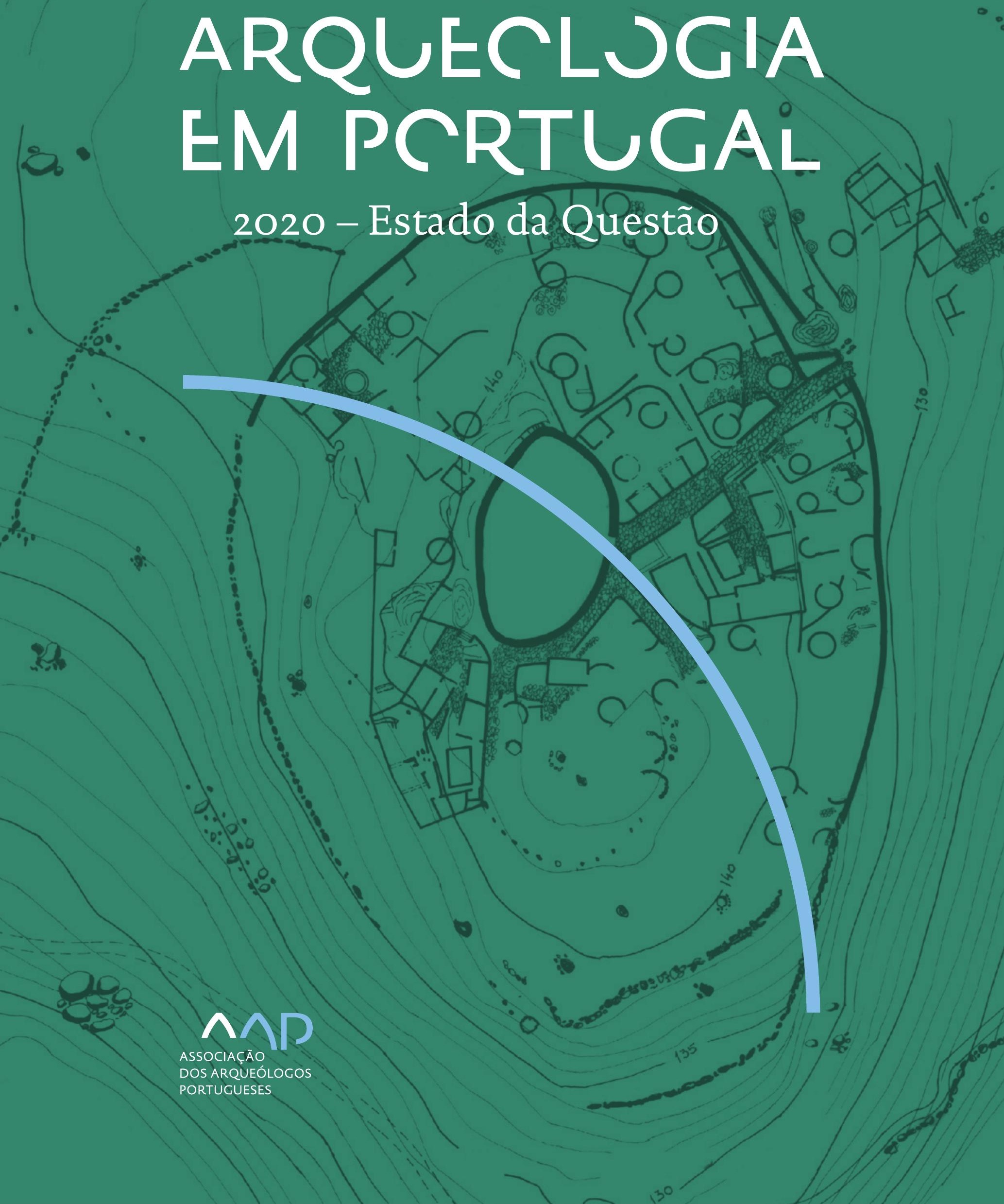


Coordenação editorial: José Morais Arnaud, César Neves e Andrea Martins Design gráfico: Flatland Design

AAP - ISBN: 978-972-9451-89-8

CITCEM - ISBN: 978-989-8970-25-1

Associação dos Arqueólogos Portugueses e CITCEM

Lisboa, 2020

O conteúdo dos artigos é da inteira responsabilidade dos autores. Sendo assim a Associação dos Arqueólogos Portugueses declina qualquer responsabilidade por eventuais equívocos ou questões de ordem ética e legal.

Desenho de capa:

Planta do castro de Monte Mozinho (Museu Municipal de Penafiel).

\section{$\hat{\wedge} \mathrm{P}$}

DOS ARQUEÓLOGOS PORTUGUESES

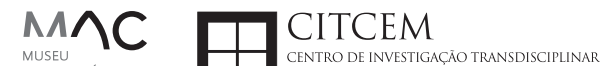
MUSEU
ARQUELLÓGICO
DO CARMO
U.PORTO

FLUP FACULDADE DE LETRAS
UNIVERSIDADE DO PORTO

Apoio

EC para a Ciência 


\section{Índice}

15 Prefácio

José Morais Arnaud

\section{Historiografia e Teoria}

17 Território, comunidade, memória e emoção: a contribuição da história da arqueologia (algumas primeiras e breves reflexões)

Ana Cristina Martins

25 Como descolonizar a arqueologia portuguesa?

Rui Gomes Coelho

41 Arqueologia e Modernidade: uma revisitação pessoal e breve de alguns aspetos da obra homónima de Julian Thomas de 2004

Vítor Oliveira Jorge

57 Dados para a História das Mulheres na Arqueologia portuguesa, dos finais do século XIX aos inícios do século XX: números, nomes e tabelas

Filipa Dimas / Mariana Diniz

73 Retractos da arqueologia portuguesa na imprensa: (in)visibilidades no feminino

Catarina Costeira / Elsa Luís

85 Arqueologia e Arqueólogos no Norte de Portugal Jacinta Bugalhão

101 Vieira Guimarães (1864-1939) e a arqueologia em Tomar: uma abordagem sobre o território e as gentes

João Amendoeira Peixoto / Ana Cristina Martins

115 Os memoráveis? A arqueologia algarvia na imprensa nacional e regional na presente centúria (2001-2019): características, visões do(s) passado(s) e a arqueologia

enquanto marca

Frederico Agosto / João Silva

129 A Evolução da Arqueologia Urbana e a Valorização Patrimonial no Barlavento Algarvio: Os casos de Portimão e Silves

Artur Mateus / Diogo Varandas / Rafael Boavida

\section{Gestão, Valorização e Salvaguarda do Património}

145 O Caderno Reivindicativo e as condições de trabalho em Arqueologia Miguel Rocha / Liliana Matias Carvalho / Regis Barbosa / Mauro Correia / Sara Simões / Jacinta Bugalhão / Sara Brito / Liliana Veríssimo Carvalho / Richard Peace / Pedro Peça / Cézer Santos

155 Os Estudos de Impacte Patrimonial como elemento para uma estratégia sustentável de minimização de impactes no âmbito de reconversões agrícolas Tiago do Pereiro

165 Salvaguarda de Património arqueológico em operações florestais: gestão e sensibilização Filipa Bragança / Gertrudes Zambujo / Sandra Lourenço / Belém Paiva / Carlos Banha / Frederico Tatá Regala / Helena Moura / Jacinta Bugalhão / João Marques / José Correia / Pedro Faria / Samuel Melro

179 Os valores do Património: uma investigação sobre os Sítios Pré-históricos de Arte Rupestre do Vale do Rio Côa e de Siega Verde José Paulo Francisco 
189 Conjugando recursos arqueológicos e naturais para potenciar as visitas ao Geoparque Litoral de Viana do Castelo (Noroeste de Portugal)

Hugo A. Sampaio / Ana M.S. Bettencourt / Susana Marinho / Ricardo Carvalhido

203 Áreas de Potencial Arqueológico na Região do Médio Tejo: Modelo Espacial Preditivo Rita Ferreira Anastácio / Ana Filipa Martins / Luiz Oosterbeek

223 Património Arqueológico e Gestão Territorial: O contributo da Arqueologia para a revisão do PDM de Avis

Ana Cristina Ribeiro

237 A coleção arqueológica do extinto Museu Municipal do Porto - Origens, Percursos e Estudos

Sónia Couto

251 Valpaços - uma nova carta arqueológica

Pedro Pereira / Maria de Fátima Casares Machado

263 Arqueologia na Cidade de Peniche

Adriano Constantino / Luís Rendeiro

273 Arqueologia Urbana: a cidade de Lagos como caso de Estudo Cátia Neto

285 Estratégias de promoção do património cultural subaquático nos Açores. O caso da ilha do Faial

José Luís Neto / José Bettencourt / Luís Borges / Pedro Parreira

297 Carta Arqueológica da Cidade Velha: Uma primeira abordagem

Jaylson Monteiro / Nireide Tavares / Sara da Veiga / Claudino Ramos / Edson Brito /

Carlos Carvalho / Francisco Moreira / Adalberto Tavares

311 Antropologia Virtual: novas metodologias para a análise morfológica e funcional Ricardo Miguel Godinho / Célia Gonçalves

\section{Didáctica da Arqueologia}

327 Como os projetos de Arqueologia podem contribuir para uma comunidade culturalmente mais consciente Alexandra Figueiredo / Claúdio Monteiro / Adolfo Silveira / Ricardo Lopes

337 Educação Patrimonial - Um cidadão esclarecido é um cidadão ativo! Ana Paula Almeida

351 A aproximação da Arqueologia à sala de aula: um caso de estudo no $3^{\circ}$ ciclo do Ensino Básico Luís Serrão Gil

363 Arqueologia 3.o - Pensar e comunicar a Arqueologia para um futuro sustentável Mónica Rolo

377 “Conversa de Arqueólogos" - Divulgar a Arqueologia em tempos de Pandemia Diogo Teixeira Dias

389 Escola Profissional de Arqueologia: desafios e oportunidades Susana Nunes / Dulcineia Pinto / Júlia Silva / Ana Mascarenhas

399 Os Museus de Arqueologia e os Jovens: a oferta educativa para o público adolescente Beatriz Correia Barata / Leonor Medeiros

411 O museu universitário como mediador entre a ciência e a sociedade: o exemplo da secção de arqueologia no Museu de História Natural e da Ciência da Universidade do Porto (MHNC-UP)

Rita Gaspar 
421 Museu de Lanifícios: Real Fábrica de Panos. Atividades no âmbito da Arqueologia Beatriz Correia Barata / Rita Salvado

427 Arqueologia Pública e o caso da localidade da Mata (Torres Novas) Cláudia Manso / Ana Rita Ferreira / Cristiana Ferreira / Vanessa Cardoso Antunes

431 Do sítio arqueológico ao museu: um percurso (também) didático Lídia Fernandes

447 Estão todos convidados para a Festa! E para dançar também... O projecto do Serviço Educativo do Museu Arqueológico do Carmo na $5^{\underline{a}}$ Edição da Festa da Arqueologia Rita Pires dos Santos

459 O “Clã de Carenque”, um projeto didático de arqueologia Eduardo Gonzalez Rocha

469 Mediação cultural: peixe que puxa carroça nas Ruínas Romanas de Troia Inês Vaz Pinto / Ana Patrícia Magalhães / Patrícia Brum / Filipa Santos

481 Didática Arqueológica, experiências do Projeto Mértola Vila Museu Maria de Fátima Palma / Clara Rodrigues / Susana Gómez / Lígia Rafael

\section{Arte Rupestre}

497 Os inventários de arte rupestre em Portugal Mila Simões de Abreu

513 O projeto FIRST-ART - conservação, documentação e gestão das primeiras manifestações de arte rupestre no Sudoeste da Península Ibérica: as grutas do Escoural e Maltravieso Sara Garcês / Hipólito Collado / José Julio García Arranz / Luiz Oosterbeek / António Carlos Silva / Pierluigi Rosina / Hugo Gomes / Anabela Borralheiro Pereira / George Nash / Esmeralda Gomes / Nelson Almeida / Carlos Carpetudo

523 Trabalhos de documentação de arte paleolítica realizados no âmbito do projeto PalæoCôa André Tomás Santos / António Fernando Barbosa / Luís Luís / Marcelo Silvestre / Thierry Aubry

537 Imagens fantasmagóricas, silhuetas elusivas: as figuras humanas na arte do Paleolítico Superior da região do Côa Mário Reis

$55^{1}$ Os motivos zoomórficos representados nas placas de tear de Vila Nova de São Pedro (Azambuja, Portugal) Andrea Martins / César Neves / José M. Arnaud / Mariana Diniz

571 Arte Rupestre do Monte de Góios (Lanhelas, Caminha). Síntese dos resultados dos trabalhos efectuados em 2007-2009 Mário Varela Gomes

599 Gravuras rupestres de barquiformes no Monte de S. Romão, Guimarães, Noroeste de Portugal Daniela Cardoso

613 Círculos segmentados gravados na Bacia do Rio Lima (Noroeste de Portugal): contributos para o seu estudo Diogo Marinho / Ana M.S. Bettencourt / Hugo Aluai Sampaio

631 Equídeos gravados no curso inferior do Rio Mouro, Monção (NW Portugal). Análise preliminar Coutinho, L.M. / Bettencourt, A.M.S / Sampaio, Hugo A.S

645 Paletas na Arte Rupestre do Noroeste de Portugal. Inventário preliminar Bruna Sousa Afonso / Ana M. S. Bettencourt / Hugo A. Sampaio 


\section{Pré-História}

661 O projeto Miño/Minho: balanço de quatro anos de trabalhos arqueológicos Sérgio Monteiro-Rodrigues / João Pedro Cunha-Ribeiro / Eduardo Méndez-Quintas / Carlos Ferreira / Pedro Xavier / José Meireles / Alberto Gomes / Manuel Santonja / Alfredo Pérez-González

677 A ocupação paleolítica da margem esquerda do Baixo Minho: a indústria lítica do sítio de Pedreiras 2 (Monção, Portugal) e a sua integração no contexto regional Carlos Ferreira / João Pedro Cunha-Ribeiro / Sérgio Monteiro-Rodrigues / Eduardo Méndez-Quintas / Pedro Xavier / José Meireles / Alberto Gomes / Manuel Santonja / Alfredo Pérez-González

693 O sítio acheulense do Plistocénico médio da Gruta da Aroeira Joan Daura / Montserrat Sanz / Filipa Rodrigues / Pedro Souto / João Zilhão

703 As sociedades neandertais no Barlavento algarvio: modelos preditivos com recurso aos SIG

Daniela Maio

715 A utilização de quartzo durante o Paleolítico Superior no território dos vales dos rios Vouga e Côa

Cristina Gameiro / Thierry Aubry / Bárbara Costa / Sérgio Gomes / Luís Luís / Carmen Manzano / André Tomás Santos

733 Uma perspetiva diacrónica da ocupação do concheiro do Cabeço da Amoreira (Muge, Portugal) a partir da tecnologia lítica Joana Belmiro / João Cascalheira / Célia Gonçalves

745 Novos dados sobre a Pré-história Antiga no concelho de Palmela. A intervenção arqueológica no sítio do Poceirão I

Michelle Teixeira Santos

757 Problemas em torno de Datas Absolutas Pré-Históricas no Norte do Alentejo Jorge de Oliveira

771 Povoamento pré-histórico nas áreas montanhosas do NO de Portugal: o Abrigo 1 de Vale de Cerdeira Pedro Xavier / José Meireles / Carlos Alves

783 Apreciação do povoamento do Neolítico Inicial na Baixa Bacia do Douro. A Lavra I (Serra da Aboboreira) como caso de estudo Maria de Jesus Sanches

797 O Processo de Neolitização na Plataforma do Mondego: os dados do Sector C do Outeiro dos Castelos de Beijós (Carregal do Sal)

João Carlos de Senna-Martinez / José Manuel Quintã Ventura / Andreia Carvalho / Cíntia Maurício

823 Novos trabalhos na Lapa da Bugalheira (Almonda, Torres Novas) Filipa Rodrigues / Pedro Souto / Artur Ferreira / Alexandre Varanda / Luís Gomes / Helena Gomes / João Zilhão

837 A pedra polida e afeiçoada do sítio do Neolítico médio da Moita do Ourives (Benavente, Portugal)

César Neves

857 Casal do Outeiro (Encarnação, Mafra): novos contributos para o conhecimento do povoamento do Neolítico final na Península de Lisboa.

Cátia Delicado / Carlos Maneira e Costa / Marta Miranda / Ana Catarina Sousa

873 Stresse infantil, morbilidade e mortalidade no sítio arqueológico do Neolítico Final/ Calcolítico ( $4^{\circ}$ e $3^{\circ}$ milénio a.C.) do Monte do Carrascal 2 (Ferreira do Alentejo, Beja) Liliana Matias de Carvalho / Sofia N. Wasterlain 
885 Come together: O Conjunto Megalítico das Motas (Monção, Viana do Castelo) e as expressões Campaniformes do Alto Minho Ana Catarina Basílio / Rui Ramos

899 Trabalhos arqueológicos no sítio Calcolítico da Pedreira do Poio Carla Magalhães / João Muralha / Mário Reis / António Batarda Fernandes

913 O sítio arqueológico de Castanheiro do Vento. Da arquitectura do sítio à arquitectura de um território João Muralha Cardoso

925 Estudo zooarqueológico das faunas do Calcolítico final de Vila Nova de São Pedro (Azambuja, Portugal): Campanhas de 2017 e 2018 Cleia Detry / Ana Catarina Francisco / Mariana Diniz / Andrea Martins / César Neves / José Morais Arnaud

943 As faunas depositadas no Museu Arqueológico do Carmo provenientes de Vila Nova de São Pedro (Azambuja): as campanhas de 1937 a 1967 Ana Catarina Francisco / Cleia Detry / César Neves / Andrea Martins / Mariana Diniz / José Morais Arnaud

959 Análise funcional de material lítico em sílex do castro de Vila Nova de S. Pedro (Azambuja, Portugal): uma primeira abordagem Rafael Lima

971 O recinto da Folha do Ouro 1 (Serpa) no contexto dos recintos de fossos calcolíticos alentejanos

António Carlos Valera / Tiago do Pereiro / Pedro Valério / António M. Monge Soares

\section{Proto-História}

987 Produção de sal marinho na Idade do Bronze do noroeste Português. Alguns dados para uma reflexão

Ana M. S. Bettencourt / Sara Luz / Nuno Oliveira / Pedro P. Simões / Maria Isabel C. Alves / Emílio Abad-Vidal

1001 A estátua-menir do Pedrão ou de São Bartolomeu do Mar (Esposende, noroeste de Portugal) no contexto arqueológico da fachada costeira de entre os rios Neiva e Cávado Ana M. S. Bettencourt / Manuel Santos-Estévez / Pedro Pimenta Simões / Luís Gonçalves

1015 O Castro do Muro (Vandoma/Baltar, Paredes) - notas para uma biografia de ocupação da Idade do Bronze à Idade Média

Maria Antónia D. Silva / Ana M. S. Bettencourt / António Manuel S. P. Silva / Natália Félix

1031 Do Bronze Final à Idade Média - continuidades e hiatos na ocupação de Povoados em Oliveira de Azeméis João Tiago Tavares / Adriaan de Man

1041 As faunas do final da Idade do Bronze no Sul de Portugal: leituras desde o Outeiro do Circo (Beja)

Nelson J. Almeida / Íris Dias / Cleia Detry / Eduardo Porfírio / Miguel Serra

1055 A Espada do Monte das Oliveiras (Serpa) - uma arma do Bronze Pleno do Sudoeste Rui M. G. Monge Soares / Pedro Valério / Mariana Nabais / António M. Monge Soares

1065 São Julião da Branca (Albergaria-a-Velha) - Investigação e valorização de um povoado do Bronze Final

António Manuel S. P. Silva / Paulo A. P. Lemos / Sara Almeida e Silva / Edite Martins de Sá

1083 Do castro de S. João ao Mosteiro de Santa Clara: notícia de uma intervenção arqueológica, em Vila do Conde Rui Pinheiro 
1095 O castro de Ovil (Espinho), um quarto de século de investigação - resultados e questões em aberto

Jorge Fernando Salvador / António Manuel S. P. Silva

1111 O Castro de Salreu (Estarreja), um povoado proto-histórico no litoral do Entre Douro e Vouga

Sara Almeida e Silva / António Manuel S. P. Silva / Paulo A. P. Lemos / Edite Martins de Sá

1127 Castro de Nossa Senhora das Necessidades (Sernancelhe): uma primeira análise artefactual Telma Susana O. Ribeiro

${ }_{1141}$ A cividade de Bagunte. O estado atual da investigação Pedro Brochado de Almeida

1153 Zoomorfos na cerâmica da Idade do Ferro no NW Peninsular: inventário, cronologias e significado Nuno Oliveira / Cristina Seoane

1163 Vasos gregos em Portugal: diferentes maneiras de contar a história do intercâmbio cultural na Idade do Ferro

Daniela Ferreira

1175 Os exotica da necrópole da Idade do Ferro do Olival do Senhor dos Mártires (Alcácer do Sal) no seu contexto regional

Francisco B. Gomes

\section{Antiguidade Clássica e Tardia}

1191 O uso de madeira como combustível no sítio da Quinta de Crestelos (Baixo Sabor): da Idade do Ferro à Romanização Filipe Vaz / João Tereso / Sérgio Simões Pereira / José Sastre / Javier Larrazabal Galarza / Susana Cosme / José António Pereira / Israel Espi

1207 Cultivos de Época Romana no Baixo Sabor: continuidade em tempos de mudança? João Pedro Tereso / Sérgio Simões Pereira / Filipe Santos / Luís Seabra / Filipe Vaz

1221 A casa romana na Hispânia: aplicação dos modelos itálicos nas províncias ibéricas Fernanda Magalhães / Diego Machado / Manuela Martins

1235 As pinturas murais romanas da Rua General Sousa Machado, n. ${ }^{5}$ 1, Chaves José Carvalho

1243 Trás do Castelo (Vale de Mir, Pegarinhos, Alijó) - Uma exploração agrícola romana do Douro

Tony Silvino / Pedro Pereira

1255 A sequência de ocupação no quadrante sudeste de Bracara Augusta: as transformações de uma unidade doméstica Lara Fernandes / Manuela Martins

1263 Os Mosaicos com decoração geométrica e geométrico-vegetalista dos sítios arqueológicos da área do Conuentus Bracaraugustanus. Novas abordagens quanto à conservação, restauro, decoração e datação Maria de Fátima Abraços / Licínia Wrench

1277 “Casa Romana” do Castro de São Domingos (Cristelos, Lousada): Escavação, Estudo e Musealização Paulo André de P. Lemos

1291 A arqueobotânica no Castro de Guifões (Matosinhos, Noroeste de Portugal): O primeiro estudo carpológico

Luís Seabra / Andreia Arezes / Catarina Magalhães / José Varela / João Pedro Tereso 
1305 Um Horreum Augustano na Foz do Douro (Monte do Castelo de Gaia, Vila Nova de Gaia) Rui Ramos

1311 Ponderais romanos na Lusitânia: padrões, formas, materiais e contextos de utilização Diego Barrios Rodríguez

1323 Um almofariz centro-itálico na foz do Mondego

Marco Penajoia

1335 Estruturas romanas de Carnide - Lisboa Luísa Batalha / Mário Monteiro / Guilherme Cardoso

1347 O contexto funerário do sector da "necrópole NO" da Rua das Portas de S. Antão (Lisboa): o espaço, os artefactos, os indivíduos e a sua interconectividade na interpretação do passado Sílvia Loja, José Carlos Quaresma, Nelson Cabaço, Marina Lourenço, Sílvia Casimiro, Rodrigo Banha da Silva, Francisca Alves-Cardoso

${ }_{1361}$ Povoamento em época Romana na Amadora - resultados de um projeto pluridisciplinar Gisela Encarnação / Vanessa Dias

1371 A Arquitectura Residencial em Mirobriga (Santiago do Cacém): contributo a partir de um estudo de caso Filipe Sousa / Catarina Felício

${ }_{1385}$ O fim do ciclo. Saneamento e gestão de resíduos nos edifícios termais de Mirobriga (Santiago do Cacém)

Catarina Felício / Filipe Sousa

1399 Balsa, Topografia e Urbanismo de uma Cidade Portuária Vítor Silva Dias / João Pedro Bernardes / Celso Candeias / Cristina Tété Garcia

1413 No Largo das Mouras Velhas em Faro (2017): novas evidências da necrópole norte de Ossonoba e da sua ocupação medieval Ricardo Costeira da Silva / Paulo Botelho / Fernando Santos / Liliana Nunes

1429 Instrumentos de pesca recuperados numa fábrica de salga em Ossonoba (Faro) Inês Rasteiro / Ricardo Costeira da Silva / Paulo Botelho

1439 A Necrópole Romana do Eirô, Duas Igrejas (Penafiel): intervenção arqueológica de 2016 Laura Sousa / Teresa Soeiro

1457 Ritual, descarte ou afetividade? A presença de Canis lupus familiaris na Necrópole Noroeste de Olisipo (Lisboa)

Beatriz Calapez Santos / Sofia Simões Pereira / Rodrigo Banha da Silva / Sílvia Casimiro / Cleia Detry / Francisca Alves Cardoso

1467 Dinâmicas económicas em Bracara na Antiguidade Tardia Diego Machado / Manuela Martins / Fernanda Magalhães / Natália Botica

1479 Cerâmicas e Vidros da Antiguidade Tardia do Edifício sob a Igreja do Bom Jesus (Vila Nova de Gaia) Joaquim Filipe Ramos

1493 Novos contributos para a topografia histórica de Mértola no período romano e na Antiguidade Tardia Virgílio Lopes

\section{8. Época Medieval}

1511 Cerâmicas islâmicas no Garb setentrional "português": algumas evidências e incógnitas Constança dos Santos / Helena Catarino / Susana Gómez / Maria José Gonçalves / Isabel Inácio / Gonçalo Lopes / Jacinta Bugalhão / Sandra Cavaco / Jaquelina Covaneiro / Isabel Cristina Fernandes / Ana Sofia Gomes 
1525 Contributo para o conhecimento da cosmética islâmica, em Silves, durante a Idade Média Rosa Varela Gomes

1537 Yábura e o seu território - uma análise histórico-arqueológica de Évora entre os séculos VIII-XII José Rui Santos

1547 A encosta sul do Castelo de Palmela - resultados preliminares da escavação arqueológica Luís Filipe Pereira / Michelle Teixeira Santos

1559 A igreja de São Lourenço (Mouraria, Lisboa): um conjunto de silos e de cerâmica medieval islâmica

Andreia Filipa Moreira Rodrigues

1571 O registo material de movimentações populacionais no Médio Tejo, durante os séculos XII-XIII. Dois casos de "sunken featured buildings", nos concelhos de Cartaxo e Torres Novas Marco Liberato / Helena Santos / Nuno Santos

1585 O nordeste transmontano nos alvores da Idade média. Notas para reflexão Ana Maria da Costa Oliveira

1601 Sepulturas escavadas na rocha do Norte de Portugal e do Vale do Douro: primeiros resultados do Projecto SER-NPVD

Mário Jorge Barroca / César Guedes / Andreia Arezes / Ana Maria Oliveira

1619 "Portucalem Castrum Novum" entre o Mediterrâneo e o Atlântico: o estudo dos materiais cerâmicos alto-medievais do arqueossítio da rua de D. Hugo, nํ. 5 (Porto) João Luís Veloso

1627 A Alta Idade Média na fronteira de Lafões: notas preliminares sobre a Arqueologia no Concelho de Vouzela

Manuel Luís Real / Catarina Tente

1641 Um conjunto cerâmico medieval fora de portas: um breve testemunho aveirense Susana Temudo

${ }_{1651}$ Os Lóios do Porto: uma perspetiva integrada no panorama funerário da Baixa Idade Média à Época Moderna em meios urbanos em Portugal

Ana Lema Seabra

1659 O Caminho Português Interior de Santiago como eixo viário na Idade Média Pedro Azevedo

1665 Morfologia Urbana: Um exercício em torno do Castelo de Ourém André Donas-Botto / Jaqueline Pereira

1677 Intervenção arqueológica na Rua Marquês de Pombal/Largo do Espírito Santo (Bucelas, Loures)

Florbela Estêvão / Nathalie Antunes-Ferreira / Dário Ramos Neves / Inês Lisboa

1691 O Cemitério Medieval do Poço do Borratém e a espacialidade funerária na cidade de Lisboa Inês Belém / Vanessa Filipe / Vasco Noronha Vieira / Sónia Ferro / Rodrigo Banha da Silva

1705 Um Espaço Funerário Conventual do séc. XV em Lisboa: o caso do Convento de São Domingos da Cidade Sérgio Pedroso / Sílvia Casimiro / Rodrigo Banha da Silva / Francisca Alves Cardoso

\section{9. Época Moderna e Contemporânea}

1721 Arqueologia Moderna em Portugal: algumas reflexões críticas em torno da quantificação de conjuntos cerâmicos e suas inferências históricas e antropológicas Rodrigo Banha da Silva / André Bargão / Sara da Cruz Ferreira

1733 Faianças de dois contextos entre os finais do século XVI e XVIII do Palácio dos Condes de Penafiel, Lisboa

Martim Lopes / Tomás Mesquita 
1747 Um perfil de consumo do século XVIII na foz do Tejo: O caso do Mercado da Ribeira, Lisboa Sara da Cruz Ferreira / Rodrigo Banha da Silva / André Bargão

1761 Os Cachimbos dos Séculos XVII e XVIII do Palácio Mesquitela e Convento dos Inglesinhos (Lisboa)

Inês Simão / Marina Pinto / João Pimenta / Sara da Cruz Ferreira / André Bargão / Rodrigo Banha da Silva

1775 "Tomar os fumos da erua que chamão em Portugal erua sancta». Estudo de Cachimbos provenientes da Rua do Terreiro do Trigo, Lisboa

Miguel Martins de Sousa / José Pedro Henriques / Vanessa Galiza Filipe

1787 Cachimbos de Barro Caulínitico da Sé da Cidade Velha (República de Cabo Verde)

Rodrigo Banha da Silva / João Pimenta / Clementino Amaro

1801 Algumas considerações sobre espólio não cerâmico recuperado no Largo de Jesus (Lisboa) Carlos Boavida

1815 Adereços de vidro, dos séculos XVI-XVIII, procedentes do antigo Convento de Santana de Lisboa (anéis, braceletes e contas)

Joana Gonçalves / Rosa Varela Gomes / Mário Varela Gomes

1837 Da ostentação, luxo e poder à simplicidade do uso quotidiano: arqueologia e simbologia de joias e adornos da Idade Moderna Portuguesa Jéssica Iglésias

1849 Os amuletos em Portugal - dos objetos às superstições: o coral vermelho Alexandra Vieira

1865 Cerâmicas de Vila Franca de Xira nos séculos XV e XVI Eva Pires

1879 «Não passa por teu o que me pertence». Marcas de individualização associadas a faianças do Convento de Nossa Senhora de Aracoeli, Alcácer do Sal Catarina Parreira / Íris Fragoso / Miguel Martins de Sousa

1891 Cerâmica de Leiria: alguns focos de produção

Jaqueline Pereira / André Donas-Botto

1901 Os Fornos na Rua da Biquinha, em Óbidos Hugo Silva / Filipe Oliveira

1909 A casa de Pêro Fernandes, contador dos contos de D. Manuel I: o sítio arqueológico da Silha do Alferes, Seixal (século XVI) Mariana Nunes Ferreira

1921 O Alto da Vigia (Sintra) e a vigilância e defesa da costa Alexandre Gonçalves / Sandra Santos

1937 O contexto da torre sineira da Igreja de Santa Maria de Loures Paulo Calaveira / Martim Lopes

1949 A Necrópole do Hospital Militar do Castelo de São Jorge e as práticas funerárias na Lisboa de Época Moderna Susana Henriques / Liliana Matias de Carvalho / Ana Amarante / Sofia N. Wasterlain

1963 SAND - Sarilhos Grandes Entre dois Mundos: o adro da Igreja e a Paleobiologia dos ossos humanos recuperados

Paula Alves Pereira / Roger Lee Jesus / Bruno M. Magalhães

1975 Expansão urbana da vila de Cascais no século XVII e XVIII: a intervenção arqueológica na Rua da Vitória no 15 a 17

Tiago Pereira / Vanessa Filipe

1987 Novos dados para o conhecimento do Urbanismo de Faro em época Moderna Ana Rosa 
1995 Um exemplo de Arqueologia Urbana em Alcoutim: o Antigo Edifício dos CTT Marco Fernandes / Marta Dias / Alexandra Gradim / Virgílio Lopes / Susana Gómez Martínez

2007 Palácio dos Ferrazes (Rua das Flores/Rua da Vitória, Porto): a cocheira de Domingos Oliveira Maia

Francisco Raimundo

2021 As muitas vidas de um edifício urbano: História, Arqueologia e Antropologia no antigo Recreatório Paroquial de Penafiel Helena Bernardo / Jorge Sampaio / Marta Borges

2035 O convento de Nossa Senhora da Esperança de Ponta Delgada: o contributo da arqueologia para o conhecimento de um monumento identitário João Gonçalves Araújo / N’Zinga Oliveira

2047 Arqueologia na ilha do Corvo... em busca da capela de Nossa Senhora do Rosário Tânia Manuel Casimiro / José Luís Neto / Luís Borges / Pedro Parreira

2059 Perdidos à vista da Costa. Trabalhos arqueológicos subaquáticos na Barra do Tejo Jorge Freire / José Bettencourt / Augusto Salgado

2071 Arqueologia marítima em Cabo Verde: enquadramento e primeiros resultados do projecto CONCHA

José Bettencourt / Adilson Dias / Carlos Lima / Christelle Chouzenoux / Cristóvão Fonseca / Dúnia Pereira / Gonçalo Lopes / Inês Coelho / Jaylson Monteiro / José Lima / Maria Eugénia Alves / Patrícia Carvalho / Tiago Silva

2085 Trabalhos arqueológicos na Cidade Velha (Ribeira Grande de Santiago, Cabo Verde): reflexões sobre um projecto de investigação e divulgação patrimonial André Teixeira / Jaylson Monteiro / Mariana Mateus / Nireide Tavares / Cristovão Fonseca / Gonçalo C. Lopes / Joana Bento Torres / Dúnia Pereira / André Bargão / Aurélie Mayer / Bruno Zélie / Carlos Lima / Christelle Chouzenoux / Inês Henriques / Inês Pinto Coelho / José Lima / Patrícia Carvalho / Tiago Silva

2103 A antiga fortificação de Quelba / Khor Kalba (E.A.U.). Resultados de quatro campanhas de escavações, problemáticas e perspectivas futuras Rui Carita / Rosa Varela Gomes / Mário Varela Gomes / Kamyar Kamyad

2123 Colónias para homens novos: arqueologia da colonização agrária fascista no noroeste ibérico Xurxo Ayán Vila / José Mạ . Señorán Martín 


\title{
COLÓNIAS PARA HOMENS NOVOS: ARQUEOLOGIA DA COLONIZAÇÃO AGRÁRIA FASCISTA NO NOROESTE IBÉRICO
}

\author{
Xurxo Ayán Vila ${ }^{1}$, José Ma ${ }^{a}$. Señorán Martín ${ }^{2}$
}

\begin{abstract}
RESUMO
A partir de uma abordagem comparativa, propomos nesta nossa comunicação uma Arqueologia de algumas das colônias agrárias implantadas no noroeste da península bérica: Lamas (Paredes de Coura), o projeto de colonização dos terrenos baldios de Montalegre e Boticas (Barroso) e o Plan de Colonización de la Tierra Llana (Lugo, Galiza). Apesar de ser uma área que compartilha características comuns (mesmo clima, pequenos proprietários, marginalidade), as soluções adotadas geraram diferentes materialidades. A partir da Arqueologia do Passado Recente, recém desenvolvida em Portugal, levantamos questões teóricas e metodológicas para o estudo desse tipo de espaço doméstico contemporâneo. Esta pesquisa é realizada no âmbito do projeto de Archaeology of Contemporary Past and Heritage Socialization, financiado pela FCT (CEECIND / 04218/2017).

Palavras-chave: Colonização agraria, Fascismo, Espaço doméstico, Arqueologia rural, Arqueologia da paisagem.
\end{abstract}

\begin{abstract}
From a comparative approach, we propose in this communication an Archaeology of some of the agrarian colonies implanted in the northwest of the Iberian peninsula: Lamas (Paredes de Coura), the colonization project of the wastelands of Montalegre and Boticas (Barroso) and the Plan de Colónización de la Tierra Llana (Lugo, Galicia). Despite being an area that shares common characteristics (same climate, small landowners, marginality), the solutions adopted have generated different materialities. From the Archaeology of the Recent Past, recently developed in Portugal, we raised theoretical and methodological questions for the study of this type of contemporary domestic space. This research is carried out within the scope of the Archaeology of Contemporary Past and Heritage Socialization project, funded by FCT (CEECIND / 04218/2017).
\end{abstract}

Keywords: Agrarian colonization, Fascism, Domestic space, Rural archaeology, Landscape archaeology.

\section{INTRODUÇÃO}

Desde o início que as ditaduras ibéricas de Salazar e Franco propuseram a criação de um novo Estado baseado na autarquia, no intervencionismo estatal no mercado, no controlo da mão-de-obra rural e na defesa da propriedade. Tudo isto para favorecer e recompensar os grandes proprietários de terras que tinham apoiado o bando rebelde no caso espanhol e que lutavam contra a mobilização política dos trabalhadores rurais nas grandes propriedades do centro-sul de Portugal (Barrones, 2012; Baptista, 1993). A colonização seria o elemento-chave desta política agrícola, apresentada em Espanha como uma reforma inteligente em contraste com a reforma agrária realizada durante a Segunda República e o processo de coletivização. Para além da transformação de milhares de hectares em terras irrigadas e da redistribuição de parcelas entre os novos colonos, o objetivo final era redimir o campesinato, uma vez que a ruralidade era apresentada pelos ideólogos fascistas como a reserva moral das nações espanholas e portuguesas (Alares, 2010; Rosas, 2018). As novas aldeias de colonização, cuja tarefa inicial era dar apoio material às pessoas que estavam a transformar os terrenos baldios em terrenos agrícolas, estavam vestidos com o

1. IHC, FCSH, Universidade Nova de Lisboa; xurxoayan@fcsh.unl.pt

2. Universidade Complutense; jose.m.senoran@gmail.com 
manto ideológico do Estado Novo e a Nueva España (Silva, 2011; Guerreiro, 2016; Flores, 2013).

A Junta de Colonização Interna (1936) promoveu a criação de novos assentamentos em Portugal seguindo as orientações de Rafael Duque (Ministro da Agricultura entre 1934 e 1940 e da Economia entre 1940 e 1944) e os ensaios prévios realizados durante a monarquia e a República (Carvalho 2018). Em 1937 a reabilitação das colónias em Leiria e Sabugal serviu de base para a definição dos modelos de povoamento que mais tarde se materializariam. Entre 1936 e 1967, foram construídas sete colónias agrícolas: Milagres (Leiria), Martim Rei (Sabugal), Pegões (Setúbal), Barroso (Montalegre e Boticas), Gafanha (Ílhavo), Boalhosa (Paredes de Coura) e Alvão (Vila Pouca de Aguiar). Por outro lado, a colonização promovida pelo regime franquista através do Instituto Nacional de Colonização (1939) foi levada a cabo em muito maior escala. De facto, afetou $2 \%$ da população ativa rural em Espanha, ou seja, cerca de 60.000 colonos com a aquisição de meio milhão de hectares. Embora tenha produzido pouca redistribuição social - cerca de 50.000 famílias até 1971 - levou a cabo uma intensa política de construção, representada por 11.000 quilómetros de valas e canais, 113.0oo hectares nivelados e 300 novas aldeias (Pérez Escolano, 2005). Em ambos os casos, estamos perante autênticos projetos de engenharia social que modificaram decisivamente o meio ambiente e a paisagem cultural de regiões rurais inteiras em prol de uma certa ideia de Progresso e Modernidade. Um projeto colonizador que apresenta enormes semelhanças com iniciativas similares realizadas por outros estados totalitários, como a Itália fascista (Stampacchia, 20oo; Samuels, 2010) ou o estado comunista etíope (González Ruibal, 2006), para citar dois exemplos que conhecemos em primeira mão.

Nas últimas décadas, foram publicados trabalhos sobre este fenómeno (sejam abordagens gerais ou particulares, limitadas no tempo ou restritas a áreas territoriais específicas) por economistas, antropólogos, historiadores, geógrafos, engenheiros agrícolas, sociólogos e políticos. No entanto, a materialidade gerada por estas políticas colonizadoras só tem despertado interesse no campo da arquitetura e do planeamento urbano. Assim, temos estudos que se centraram no trabalho dos arquitetos das povoações e na análise dos projetos de ação (Centellas, 2010; Tordesillas e Meiss, 2013; Flores, 2013; Guerreiro, 2016; Oliveira, 2018). Estas abordagens têm dado uma valiosa contribuição, já que conseguiram recuperar para as Ciências Sociais uma experiência que, como dissemos, foi praticamente esquecida. No entanto, é de notar que estes estudos mal abordam o contexto sociopolítico e económico que explica o surgimento destas arquiteturas. Até agora, os aspetos estéticos e mesmo artísticos desses ambientes arquitetónicos têm sido mais tratados, deixando de lado a sua relação com a ideologia dominante e o projeto social imposto pela ditadura.

Acreditamos que a arqueologia do passado contemporâneo pode preencher esta lacuna e proporcionar uma nova abordagem às materialidades e memórias do processo de colonização. Neste sentido, em 2014 os autores deste texto iniciaram um projeto ( $\mathrm{Ar}$ queología postcolonial na Espanha) da Universidade do País Basco onde começámos a estudar arqueologicamente as colónias agrícolas e industriais promovidas pelo regime franquista em zonas como o vale do rio Alagón (Cáceres, Estremadura) (Señorán e Ayán, 2015) ou o vale do rio Sil (León, Ourense, Lugo) (Ayán e Señorán, 2015). Agora, no âmbito de um novo projeto ${ }^{3}$, pretendemos realizar um estudo comparativo das aldeias de colonização criadas pelas duas ditaduras ibéricas.

O primeiro estudo de caso centra-se na zona de pequenos proprietários da Galiza e do norte de Portugal, onde a dispersão do habitat e do regime de propriedade condicionou significativamente o projeto de colonização. Como já mencionámos, os planos de colonização na Nueva España foram criados com a intenção clara de intervir nas áreas de latifúndio do Estado onde o conflito sobre a propriedade da terra tinha gerado um profundo conflito social. Isto explica porque os grandes projetos colonizadores foram desenvolvidos na metade sul da península (Plano Jaén, Plano Badajoz), enquanto no Atlântico e no norte, não foram estabelecidos colonos, exceto no caso excepcional do noroeste. A Galiza serviu de enquadramento para quatro experiências colonizadoras: a rede de irrigação de Terra de Lemos (Lugo), a dissecação da Lagoa de Antela (A Limia, Ourense), o repovoamento da ilha de Ons (Pontevedra) e a colonização de A Terra Chá (Lugo). Vamos centrar-nos neste último caso, comparando-o com os assentamentos portugueses de A Boulhosa (Paredes de Coura) e Barroso (Montalegre e Boticas).

3. Archaeology of Contemporary Past and Heritage Socialization, financiado pela FCT (CEECIND / 04218/2017). 
Infelizmente, as circunstâncias impostas pela pandemia da COVID-19 nos últimos meses impediram-nos de completar o trabalho de campo necessário para podermos apresentar aqui um avanço mais elaborado da investigação. Em qualquer caso, aproveitamos a oportunidade para apresentar algumas reflexões e avaliar o potencial de uma linha de trabalho em arqueologia do passado recente que ainda está a descolar em Portugal (Coelho e Ayán, 202O; Casimiro e Sequeira, 2020).

\section{DO AGRO PONTINO ÀS «AGRAS» DA «TIERRA LLANA»: UM MODELO DE COLONIZAÇÃO FASCISTA NA GALIZA}

Em 2009, o ciclone Klaus derrubou uma antena de 112 metros de altura no lugar de Arneiro (Cospeito, Lugo). Este era o último vestígio material do complexo Elektra Sonne, construído pela Alemanha nazista com equipamento da casa Telefunken para guiar os submarinos da Kriegsmarine e aos caças da Luftwaffe. A torre de Arneiro, como as ruínas das explorações de volfrâmio na Galiza (Tejerizo e Rodríguez, 2020), são materiais que testemunham a ajuda dada por Franco a Hitler, em troca dos serviços prestados pelo Terceiro Reich durante a guerra civil espanhola. Tanto a antena como o aeródromo anexo de As Rozas, permaneceram ativos após a $2^{\underline{a}}$ Guerra Mundial, desta vez já em mãos espanholas.

Em 1953, um avião militar sobrevoou o Arneiro com uma nova missão. É preciso lembrar que, no período imediato do pós-guerra, o exército de Franco colaborou estreitamente no desenvolvimento da fotografia aérea como uma ferramenta útil para os cientistas e técnicos fascistas comprometidos com a Nova Espanha. Assim, os falangistas Julio Martínez Santa-Olalla (1905-1972) e Martín Almagro Basch (1911-1984) foram os primeiros a utilizar a aviação militar para a deteção de sítios arqueológicos (Almagro, 1953). O mesmo fizeram, mas na área da agricultura, Rafael Cabestany de Anduaga (19021958) e Odón Fernández Lavandera (1915-2001), os dois engenheiros agrícolas que naquela manhã de 1953 observaram do ar a manta arborizada que cobria esta área de planície conhecida como Terra Chá. Cabestany trabalhou na Guiné Equatorial entre 1925 e 1931 e nessa colónia fundou a Companhia Agrícola e Florestal. Filiado ao Falange, quando a guerra eclodiu mudou-se para a zona franquista e lutou como alferes na 150 ${ }^{\underline{a}}$ Divisão marroquina nas batalhas de
Guadalajara, Teruel e Ebro. Em 1951 foi nomeado Ministro da Agricultura por Franco, cargo que ocupou até 1957. Por sua vez, Fernández Lavandera foi diretor-geral de Agricultura e um dos responsáveis técnicos pelos projetos propostos pelo Instituto $\mathrm{Na}$ cional de Colonização na Galiza. Tanto os arqueólogos Julio e Martín, como os engenheiros agrícolas Rafel e Odón, todos os quatro fascistas, são bons exemplos daqueles ingenieros de Franco (Camprubí, 2017), especialistas que conceberam e implementaram as políticas de modernização de um regime baseado nas sinergias entre fascismo, nacional-catolicismo, ciência e tecnologia. Portanto, a colonização agrícola na Galiza foi obra de homens (somente homens) com nome e apelidos, de técnicos que desenharam todo um projeto de engenharia social como foi, neste caso, a criação da Zona de Colonização da Tierra Llana.

Do avião, o ministro e o diretor viram um imenso terreno baldio, não cultivado e sem uso, que tinha de ser colocado em produção. Do mesmo modo que drenavam sapais e lagoas insalubres (Antela na região ourensana de A Limia), aqui foi proposta a expropriação por utilidade pública da terra, o desmatamento maciço e a concentração parcelária. O que estes engenheiros agrícolas não viam era a paisagem rural tradicional das comunidades locais. Como ficou demonstrado pela história agrária, os camponeses destas paróquias mantinham um sistema de exploração sustentável em que a floresta e a montanha desempenharam um papel fundamental, como complemento da agricultura intensiva desenvolvida nas chamadas agras (Cabana, 2008). O uso comunal destes espaços tem sido regido pelo direito consuetudinário desde os tempos medievais. Esta paisagem dizia respeito a uma lógica camponesa diametralmente oposta à racionalidade manejada pelo INC. Não eram terrenos baldios e as pessoas viviam lá.

Desde a elaboração do Plano Geral, em 1956, a história tecnocrática foi baseada numa visão colonial que contribuiu para subordinar ainda mais os habitantes da área. Os técnicos queriam criar uma nova realidade en donde no hay nada, apontavam uma e outra vez hábitos rutinarios destes camponeses primitivos (Fernández e Pizarro, 1980) e propunha-se a colonização como uma missão, como aquelas que realizavam as ordens religiosas nas zonas rurais para recristianizar os habitantes do pagus. Para Cavestany, a colonização foi uma tarefa fundamental tanto nas colónias africanas como na Espanha rural, uma 
missão necessária para conduzir os Bubis, os Fang e os camponeses galegos pelos caminhos do progresso e da modernidade.

A expropriação por utilidade pública das florestas comunitárias foi um golpe para a oposição e resistência da população local. O Estado, como noutras regiões do país, recrutou a nova população de colonos entre os expulsos pela construção de barragens e pelo reflorestamento maciço. Neste caso, mais de $20 \%$ dos colonos vieram de zonas montanhosas afetadas por estes processos, como Quiroga ou Negueira de Muñiz. Foi necessário recrutar famílias de outras regiões espanholas (León, Cantábria) e mesmo do norte de Marrocos, que recentemente se tinha tornado independente de Espanha (Cardesín, 1987). Na sua vida anterior, os colonos faziam parte do grupo mais baixo da sociedade camponesa galega, conhecidos como caseiros, as famílias sem casa ou terra própria, que trabalhavam e viviam na terra de casas grandes em troca de uma parte da colheita. Estes caseiros passaram de dependentes dos fidalgos e dos camponeses ricos, a ficar dever tudo agora ao regime franquista. A construção desta nova identidade foi um instrumento de controlo social concebido pela ditadura para acabar com os caprichos da reforma agrária republicana e a luta de classes no campo. Esperava-se que os colonos fossem leais ao regime, razão pela qual muitos deles foram selecionados de entre antigos combatentes da guerra civil e da Divisão Azul (no caso português exigia-se ser, entre outras coisas, robusto, ter amor ao trabalho e à família, não ser alcoólico, nem desordeiro, nem comunista, acatar a Constituição em Fonseca 2004: 79)

Como já mencionámos, a colonização da Terra Chá foi o único caso na Galiza que levou à instalação efetiva de populações. Após a anterior expropriação de 2800 Ha de floresta comunal pertencente a freguesias dos municípios de Cospeito e Castro de Rei, 189 famílias de colonos foram reassentadas em Matodoso (Setor III, 1959-1962), em Arneiro e Veiga do Pumar (Setor II) e A Espiñeira (Setor I), estas duas últimas habitadas desde 1966 (Cardesín, 1987). Engenheiros agrícolas como Odón Fernández tiveram um papel essencial na definição deste modelo de ocupação colonial, e não tanto os arquitetos que colocaram no mapa as ideias prévias, com Alejandro de la Sota (1913-1996) como figura principal (Zas Gómez, 2002).

O projeto não pode ser compreendido sem reconhecer a influência decisiva do fascismo italiano. Tanto as instituições criadas pelo Estado Novo na década de 1930 como pelo Nuevo Estado são uma imitação das entidades promovidas pelo regime de Mussolini (Rosas, 2019). O INC nasce em 1939, no auge da fase mais filofascista da ditadura. Os ideólogos e técnicos falangistas olham com admiração para o trabalho do Duce. É a partir destas coordenadas que o Plano de Colonização da Planície reproduz, em menor escala, obviamente, o modelo do Agro Pontino, ao sul de Roma. Mussolini pretendia resolver o problema do desemprego no mundo rural enviando habitantes de áreas densamente ocupadas para repovoar áreas marginais que estavam a ser colonizadas. É a mesma lógica demográfica (e também o mesmo imaginário de dominação) que utilizou para justificar a aventura colonial na Cyrenaica Líbia e no Corno de África: o Imperio del Lavoro. Como aponta L. Veracini (2018, p. 19), o Agro Pontino é o paradigma da Bonifica integrale, de uma região definida pelos seguintes epítetos: desabitada, bárbara, primitiva, selvagem e improdutiva. A sua drenagem e ruralização contribuiria para a autonomia nacional e para a criação de uma classe de colonizadores-proprietários-cooperativos que acabaria com os conflitos gerados pelo latifúndio e o perigo de uma revolução socialista (Stampacchia, 200o). Este projeto megalomaníaco e propagandístico começou em 1927 com a drenagem e loteamento do território; em poucos anos 30.000 colonos chegaram à região e 3.000 fazendas, 88 aldeias e cinco novas cidades foram construídas (Littoria, Sabaudia, Pontinia, Aprilia e Pomezia). Como o Imperador Augusto, o ditador modificou a paisagem numa escala nunca antes vista, para reinstalar os seus legionários, os cidadãos fascistas, nas colónias rurais: un esercito di fieri rural fascisti. A Opera Nazionale per i Combattenti (ONC) selecionava os colonos e atribuía-lhes uma casa e uma parcela de terra para cultivo. Aos 30 anos, a propriedade passava para as famílias. Este modelo de habitat disperso baseava-se em núcleos centrais, centros cívicos administrativos suburbanosem que se encenava o poder (a Câmara Municipal, a Casa do Partido Fascista), e se ofereciam serviços civis (mercado, espaços de lazer) e religiosos (igreja) (Capresi, 2019). A piazza era o forum do fascismo do século XX. As missas dominicais ou eventos do partido fascista eram praticamente as únicas redes de sociabilidade fora da vida familiar nas fazendas. As colónias eram ilhas de italianidade, formavam uma feliz Arcádia rural e os colonos eram o epítome do uomo novo, o homem 
novo. A Nueva España e o Estado Novo assumiram mimeticamente esta proposta ideológica tanto nas colónias internas como nas colónias em África (Rosas, 2001; Gonçalves, 2018).

O INC conhecia perfeitamente a experiência fascista italiana desde a sua fundação. Mesmo em 1951, ex-chefes do projeto do Agro Pontino visitaram Espanha e deram palestras para engenheiros e arquitetos ligados aos projetos de colonização (Bazán e Lozano, 2015, pp. 207-9). É sobre esta base que assentou a colonização da Tierra Llana, resultando numa paisagem que desde então será familiar e será associada à modernização das zonas rurais na Galiza. Os marcos materiais são, por um lado, os canais de irrigação e, por outro, os caminhos retos que atravessam e delimitam o terreno concentrado e ao pé do qual as novas quintas familiares se estabelecem equidistantes. O módulo carro (substituído pelo módulo trator na década de 1960) estabelece uma distância mínima $(2,5$ e $3 \mathrm{~km})$ entre a casa-parcela e a casa-centro cívico (Zas, 2002, p. 199). O horizonte está pontilhado com os novos símbolos da Modernidade: os tanques de água, os silos cilíndricos e as torres dos campanários das igrejas localizadas nos centros cívicos. Num período de tempo muito curto, passamos das paróquias aos setores, das agras às parcelas, dos carros aos tratores, dos tradicionais espigueiros aos silos, da lareira, dos quinqués e das velas à luz elétrica, das cortes das vacas debaixo da casa aos estábulos de cimento, dos agricultores e caseiros aos colonos, desde os mortos no átrio da igreja paroquial até aos mortos segmentados da comunidade e enterrados em cemitérios isolados.

As fazendas consistem numa casa típica com alpendre, uma planta retangular e dois andares, e uma série de anexos (celeiro, chiqueiro, estábulo, galinheiro, monturo) ao redor de um grande pátio. $\mathrm{Na}$ casa são utilizadas técnicas tradicionais de construção, com ardósia no telhado e paredes de alvenaria. Como novidade, e seguindo o modelo do colonizador do sul, o exterior da casa é coberto com cal. A conceção (1957) foi obra não só de arquitetos, mas também de engenheiros agrícolas, o que explica a abordagem produtivista que rege este modelo de espaço doméstico. Ao mesmo tempo, o centro cívico, como já assinalámos, é uma clara adaptação do modelo fascista italiano, uma nova realidade (fracassada) que rompe com a organização paroquial galega de mil anos e com as câmaras municipais criadas no século XIX pelo Estado liberal. Em torno de uma praça ajardinada e geralmente com secções porticadas estão dispostas a Igreja, a sede da Ação Católi$\mathrm{ca}$, as escolas, as casas dos professores, instalações comerciais e um centro corporativo. Na periferia do complexo está o novo cemitério, sempre localizado em localizações conspícuas de grande visibilidade. O caso do Arneiro é paradigmático a este respeito. O centro cívico simbolizava a proteção do Estado franquista, o mesmo que tinha provocado o desenraizamento destes caseiros e camponeses, deslocados pelas obras públicas do regime. Não importava, eles deviam tudo à Nueva España. Como os montanheses de Leão que foram enviados para a terra de Campos em Castela (protagonistas do romance de Julio Llamazares Diferentes formas de mirar al agua), ou os camponeses neolíticos pré-históricos, estes novos colonos começaram realmente a ocupar o espaço quando começaram a enterrar os seus mortos nestes cemitérios tão modernos. Na sociedade camponesa galega, os nichos são agrupados sob o nome ou apelido de uma casa. Aqui não, são propriedade de pessoas com nomes e apelidos. $\mathrm{O}$ indivíduo, tal como o trator, o cimento e a luz elétrica, é uma criação da Modernidade.

\section{PLANIFICAÇÃO RURAL SALAZARISTA: O NÚCLEO DE COLÓNIAS DO BARROSO (MONTALEGRE E BOTICAS)}

$\mathrm{O}$ arquiteto nazi Albert Speer desenhou toda uma estratégia de propaganda para promover a cultura do Terceiro Reich em países neutros durante a Segunda Guerra Mundial. Foi neste contexto que se enquadrou a exposição itinerante A Moderna Arquitetura Alemã inaugurada em Lisboa em novembro de 1941, com o apoio do Sindicato Nacional dos Arquitetos e da Sociedade Nacional de Belas-Artes (Vilanova, 2014; Ninhos, 2017, pp. 222-226). O que ali se viu teve uma influência notável, não tanto na adoção da arquitetura moderna, mas no desenvolvimento da arquitetura oficial monumentalista e classicista do Estado Novo, como se pode ver no projeto da Cidade Universitária de Coimbra (1943). O arquiteto Raul Lino, presente no jantar de gala oferecido a Speer após a abertura da exposição, também não se deixou levar pela arquitetura moderna. A sua visão do que deveria ser a casa portuguesa, seja num bairro económico ou numa colónia agrária, materializava duas ideias-chave da ideologia do Estado Novo: o culto à família e a reivindicação do mundo rural. A arquite- 
tura colossal estava reservada para as grandes cidades. A arquitetura vernacular era suficiente para os camponeses e colonos. Foi neste contexto, e sob esta influência, que os arquitetos do regime (Vasco Lobo, Alfredo da Mata Antunes, António Trigo, José Luiz Pinto Machado, entre outros) começaram a planear as habitações e povoações promovidas pela JCI.

O plano de colonização de Barroso foi concebido em 1943 no âmbito da típica política fascista de promoção da autossuficiência alimentar. Era a altura das campanhas a favor da produtividade agrária e da cultura da batata (1939-1943). Para os engenheiros agrónomos que trabalham no Estado Novo, os baldios montanhosos concentrados no norte foram um obstáculo para a modernização do mundo rural. Os usos comunais e sazonais destes recursos decorriam de práticas medievais que colidiam com uma utilização racional do meio (Freire, 2004). Os técnicos definem um cliché para a identidade barrosã, criadores de gado primitivos e promíscuos ancorados no passado, selvagens que convivem com os animais, cabaneiros e cabaneiras que ocupavam o último lugar da sociedade rural e estavam nos antípodas da imagem da família cristã defendida pelo Estado Novo (Freire et al., 1998). Uma agricultura eficiente exigia o estabelecimento de camponeses mais avançados, daí que muitos colonos tivessem vindo do Alto Minho e de Viseu. Também na Terra Chá os colonos provenientes de Cantábria ensinaram boas práticas agrícolas aos primitivos nativos.

Como no caso espanhol, o projeto colonizador assentava em três pilares: a concentração parcelária, o repovoamento florestal e as infraestruturas hidráulicas. A colonização do Barroso teve lugar na década de 1950, afetando 36.477 hectares e levando à construção de sete núcleos habitacionais: Chã, Sepeda, Criande, Vidoeiro, Fontão, Pinhal Novo e Veiga de Montalegre (Oliveira, 2018). O modelo do tipo de casa concebido pelos arquitetos baseava-se numa peça principal com planta retangular, seguindo padrões já experimentados na Itália e Espanha. O espaço doméstico contava com edifícios especializados: dois silos, uma nitreira, estábulo, compartimento para pocilgas e um alpendre para carros e ferramentas. Ao contrário do habitat disperso da Terra Chá, no Barroso apostou-se na concentração das casas em assentamentos, seguindo o conceito de Unidade de Vizinhança e sob a influência anglo-saxónica da Aldeia-Jardim (Rapazote, 2012). No entanto, como no caso da Galiza, existiam aldeias centrais como a
Aldeia Nova do Barroso, com uma distância máxima de $2 \mathrm{~km}$ a pé das aldeias satélites (módulo carro em Espanha e mochav em Israel). Como aponta Silva (2011), é muito interessante ver as mudanças na evolução do projeto original. Em 1953 foi concebido um espaço segmentado do resto, com personalidade própria: o Centro Social, uma imitação do Centro Cívico do Fascismo Italiano, que, como vimos, estava também a ser aplicado na altura no noroeste de Espanha. Este núcleo acolhe materialmente os representantes do Estado Novo: professores, engenheiros e GNR. Funcionários públicos separados espacialmente dos subordinados administrados (os colonos), tal como acontecia no Ultramar e já tinha sido praticado pelos ocupantes italianos no Corno de África.

Este peculiar urbanismo rural combinava tradição e modernidade. As casas seguem modelos locais adaptados ao clima, com grandes chaminés, chão de terra batida e um telhado de duas águas (originalmente, foi ponderada a possibilidade de utilizar colmo nas coberturas), bem como práticas domésticas que enfatizam a cozinha e a vida familiar em espaços comuns. No espaço público, como nas antigas aldeias da zona, construem-se lavadouros e fornos comunais como espaços indispensáveis à socialização. No entanto, os núcleos também são desenhados com critérios modernos longe do folclore local, com rotundas, plantas circulares, jardins, áreas arborizadas e até escadas e miradouros monumentais (Rapazote, 2012). Todo esse cenário suburbano sanciona o projeto ideológico do Estado Novo, com a igreja e a escola em lugares de destaque. Este interesse estético também pode ser visto nas obras de engenharia hidráulica e nos povoados de empresa construídos nos dois países desde finais dos anos 50 (Ayán e Señorán, 2015).

Enquanto o projeto inicial nos anos 40 falava de fazendas familiares autossuficientes, já nos anos 50 o objetivo era a criação de empresas agrícolas familiares. Como no caso galego, a colonização finalmente procurou capitalizar as zonas rurais e incluí-las na lógica do mercado capitalista, mas foi totalmente confrontada com o processo de desintegração das comunidades rurais da zona a partir dos anos 60 (abandono do campo, emigração, envelhecimento). O símbolo desta política fracassada é a construção da barragem de Pisões pela Hidroelétrica do Cávado, que em 1963 inundou $24 \%$ da Aldeia Nova, $58 \%$ da Aldeia de Criande, cortou a estrada de acesso e isolou muitas parcelas. 
Numa reportagem recente, ${ }^{4}$ em março de 2019, o vice-presidente da câmara municipal de Montalegre mostrou o seu desconforto com a situação de abandono por que tinha estado a passar a zona perante a inação estatal e reclamou a cessão e utilização pública das casas dos engenheiros da JCI, abandonadas à sua sorte num pinhal próximo à barragem. $\mathrm{O}$ que antes tinha sido uma Aldeia Nova é agora uma ruína (Figura 1).

\section{A COLÓNIA NEOLÍTICA DE A BOULHOSA (LAMAS, VASCÕES, PAREDES DE COURA)}

O pré-historiador marxista Vere Gordon Childe foi convidado a visitar Portugal em dezembro de 1949. Tal como na Espanha de Franco, o reconhecido arqueólogo australiano foi homenageado por representantes académicos, neste caso, do Estado Novo (Gonçalves, 2011). Childe aproximou-se do Norte para visitar as citânias de Sanfins, Briteiros e o castro de Sabroso. Se tivesse visitado Paredes de Coura poderia ter conhecido a paisagem megalítica pré-histórica de Chã de Lamas. Childe foi o grande teórico da revolução neolítica e da sua expansão por toda a Europa. Os primeiros camponeses colonizaram novos espaços e semantizaram-nos com a construção de monumentos funerários. O núcleo megalítico de Chã de Lamas, perto da Lagoa da Salgueirinha, é a evidência material da primeira colonização humana deste território selvagem na bacia superior do rio Coura. Em 1881 Narcizo A. Cunha e Pestana de Vasconcelos escavaram a mamoa 3, expondo uma câmara funerária poligonal, constituída por cinco lajes (Silva, 2006). Neste sentido, a colónia agrária da Boalhosa significou um regresso do Estado Novo à pré-história, mas na década de 1950. Esta ideia de continuidade histórica entre os primeiros colonos e os camponeses de hoje esteve sempre presente na mente dos técnicos que realizaram a pesquisa antes do desenho da colónia agrária salazarista. Os pastores e agricultores da região eram vistos como aqueles moradores mesolíticos primitivos que não conseguiam avançar em termos evolutivos. A nova colónia, como o Neolítico, deveria trazer progresso e inovação, o desenvolvimento de uma agricultura racional e moderna, mas ancorada nos valores conservadores da tradição e da propriedade da terra.

4.https://sicnoticias.pt/programas/reportagemespecial/ 2019-03-31-Os-ultimos-colonos
O Estado Novo chegou à paisagem rural tradicional de Paredes de Coura sob a forma de uma nave alienígena. Os arquitectos que conceberam colónias agrárias sob os regimes fascistas eram capazes de gerar realidades geométricas nunca antes vistas. A modernidade aterrou sob a forma de círculos, semicírculos e casas geminadas. A colónia agrícola de A Boalhosa, ao longe, parece um OVNI encalhado numa planície neolítica. O projeto começou em 1952 e os primeiros colonos foram instalados em 1957. Os engenheiros agrónomos do Estado Novo viam o sopé da serra de Corno de Bico um espaço virgem para o desenvolvimento da agricultura. A sua particular visão dos baldios não se importava com os processos históricos. A área já tinha sido colonizada pelos primeiros camponeses na Europa, pelas comunidades neolíticas que marcaram a sua presença no território através dos seus antepassados há milhares de anos. Assim, a necrópole megalítica de Chã de Lamas, ao pé da colónia agrícola de 1954 ainda está preservada.

$\mathrm{Na}$ Boalhosa, o arquiteto António Trigo aplicou o modelo de aldeia-jardim já experimentado no Barroso e escolheu 15 habitações geminadas com cobertura de duas águas e capacidade para 30 famílias. O design da casa modelo deve-se a José Luiz Pinto Machado (Guerreiro, 2016, p. 175). No topo, em torno da "Praceta do Centro Social”, foram construídas a escola e a casa do professor, dois edifícios que devido ao seu design moderno rompem com o padrão formal folclórico das casas dos colonos. A igreja e o posto médico nunca se materializaram devido à falta de financiamento. O modelo arquitetónico ruralizante é evidenciado pela notável presença em cada unidade doméstica de um espigueiro tradicional, normalmente localizado na esquina do terreno, com visibilidade direta da rua. À entrada da colónia, o primeiro edifício a ser visto é o forno comunitário, atualmente local social da associação de moradores. Em 1958, os primeiros colonos chegaram e ocuparam 14 casas, elevando o número total de habitantes para 70. Em 1973, das 30 casas planeadas, apenas tinham sido ocupadas 10.

Hoje, visitar a colónia é uma verdadeira viagem sideral. A estrada de acesso é marcada por monólitos com o nome de diferentes planetas: aqui Saturno, ali Marte. Cientistas conceberam um percurso pedestre completo, um trilho do sistema solar de $8,6 \mathrm{~km}$ de distância. Um projeto espetacular e do qual participam diferentes entidades de olhos postos na valorização do mundo rural. Esta viagem interplanetária 
pode ser completada sem se obter qualquer informação histórica sobre esta aldeia criada ex novo. Assumimos que o Centro de Educação e Interpretação Ambiental da Paisagem Protegida de Corno de Bico (fechado) irá albergar algo daquilo que foi a história da colónia, embora já tenha suficiente com o facto de ser o centro do sistema solar. Uma antiga placa na Rua do Cimo é a única fonte que cita a origem e a função deste assentamento humano. O breve texto fala sobre os benefícios da colonização agrária dos baldios no Estado Novo.

\section{BALANÇO E PERSPETIVAS}

Está um dia quente no final de junho, a meio da manhã. Acabámos de sair do estado de emergência. A praça e e a área ajardinada do Centro Cívico de Matodoso (Castro de Rei, Terra Chá) está cheia de vegetação. O dono do bar El Centro orgulha-se da história da colónia, quando esta era uma ilhota de modernidade na Terra Chá: tínhamos escola, maquinaria, tecnologia, vida... e está tudo acabado. As pessoas foram embora e todos os serviços estão concentrados na capital do concelho de Castro de Rei. O passado colonial é um empecilho para a classe política local. A aventura da colonização interna teve, com o fim do regime de Franco, também um mau fim. Entre a relva que cobre o local do centro cívico, há um monumento ilegal bem cuidado, localizado numa posição central, na entrada do povoado e na beira da estrada: uma placa de bronze, com a efígie do ditador, diz o seguinte: SIENDO FRANCISCO FRANCO CAUDILLO DE ESPAÑA - TERRA CHA AÑO 1968.

Gerar um grupo social fiel aos regimes ditatoriais ibéricos foi um dos objetivos da colonização agrária. Materialidade, arquitetura e tecnologia contribuíram para construir esta nova identidade. Os colonos eram entes subalternos, crianças por reeducar (missões religiosas, Obra de Mães pela Educação Nacional, Educación y Descanso) aos quais era preciso "racionalizar» através da instrução correta na agricultura moderna. Os colonos eram diretamente governados por técnicos, que supervisionavam a produtividade e o seu trabalho diário. Os engenheiros, símbolos do Estado, foram os verdadeiros tutores destas comunidades criadas ex novo. Fernando Rosas, para o caso português, salientou também o elitismo cientificista do salazarismo; segundo ele, o Estado Novo promoveu todo um projeto neo- -fisiocrático de promoção rural e de reforma agrária, baseado num neo-iluminismo tecnocrático e autoritário comandado por uma elite de engenheiros (Rosas, 2019, p. 144)... e arquitetos, acrescentamos nós. E estes engenheiros de Salazar e Franco ainda hoje são reverenciados, literalmente. No bar de Matodoso, numa parede com iluminação própria, encontramos pendurado o retrato de Odón Fernández Lavandeira (Don Adón para os vizinhos, com a), o criador desta nova realidade. Os seus restos mortais encontram-se no cemitério vizinho do Centro Cívico do Arneiro. O túmulo, num lugar preferencial, recebe o visitante assim que atravessa a porta. Foi pago por assinatura popular entre os colonos, que o nomearam Filho Adotivo. Como os párocos enterrados nos átrios das igrejas galegas, este engenheiro tornou-se uma espécie de santo ou Bom Pastor. A própria propaganda de Franco explorou esta imagem do Caudilho como o Bom Pastor, após a celebração do Congresso Eucarístico Nacional em Barcelona em 1952 (Figura 2).

Esta visão apologética, triunfalista e aparentemente apolítica tornou-se muito difundida entre os descendentes daqueles colonos, como pudemos ver pelos autores deste texto durante o trabalho de campo. Nos últimos anos, tem havido uma proliferação de placas comemorativas, pequenos monumentos em praças de aldeia e centros de interpretação que honram a memória dos pioneiros (Señorán e Ayán, 2015). A aventura colonial é vista com condescendência, assumindo uma abordagem narcotizante do passado. Na colónia da Boalhosa, prevalece o discurso naturalista: é sempre mais confortável e menos controverso abrigar um Centro de Educação e Interpretação Ambiental de uma Paisagem Protegida ou uma rota interplanetária. Outra coisa seria divulgar o passado recente da área e recuperar o seu sentido de lugar. No caso da Terra Chá, não só este passado não é óbvio, como ainda se reivindica com orgulho este passado franquista.

As ruínas e restos materiais destas colónias do noroeste desafiam-nos diretamente e lembram-nos que estamos diante de um cenário político, um laboratório social projetado e executado de acordo com uma ideologia específica por especialistas com nomes e apelidos (Saraiba, 2010; Camprubí, 2017). São a expressão material da propaganda e da cosmovisão fascista (Capresi, 2019). Embora os projetos de colonização fossem herdeiros de uma tradição liberal anterior e os técnicos portugueses e espanhóis se 
inspirassem em iniciativas desenvolvidas em vários países (da Colômbia à Bélgica, passando pela Tunísia e Argélia), a JCI e o INC bebiam diretamente das fontes do fascismo italiano. Os falangistas optaram por uma arquitetura radicalmente moderna e por um habitat disperso na Terra Chá, enquanto os arquitetos do Estado Novo assumiram um habitat concentrado e um estilo regionalista que gradualmente se abriu a critérios modernos no nível do assentamento. Em ambos os casos, os regimes levaram a cabo uma política de depredação do território (expropriações, barragens, consolidação de terras, reflorestamento) que levou à mobilização forçada das populações rurais e a uma notável resistência das comunidades locais (Fonseca, 2004; Cabana, 2008). Tanto em Lugo como em Paredes de Coura ou Barroso, os habitantes das aldeias desenvolveram diferentes estratégias de resistência. A oposição e a apatia levaram ao recrutamento de colonos em lugares como Marrocos, no caso da Galiza, e em outras regiões, no caso de Portugal. O próprio dirigismo implícito nesta arquitetura planeada falhou diante da realidade de alguns colonos que reinterpretaram, readaptaram e ressignificaran espaços domésticos e agrícolas (o mesmo fizeram os arquitetos e engenheiros ao longo das décadas de 1940, 1950 e 1960).

A arqueologia é uma ferramenta útil aqui. A nossa intenção no próximo ano é realizar escavações arqueológicas em casas abandonadas nestas colónias com o objetivo de analisar qual foi a utilização real de toda esta arquitetura doméstica e se o projeto de engenharia social da colonização atingiu algum dos seus objetivos. Embora talvez as próprias ruínas sejam a evidência mais objetiva do fracasso de uma colonização que se estava a tornar cada vez mais anacrónica e extemporânea. O eletrofascismo impôs um novo campo de jogo com a chegada da barragem, no caso de Barroso. Aqui o Estado Novo pretendia deslocar os habitantes para outras zonas do país ou mesmo enviá-los para as colónias agrárias de Angola e Moçambique, outras ilhas de portugalidade nos confins do Império (Gonçalves, 2018). No entanto, após receber a indemnização, a grande maioria dos colonos tornou-se emigrante, indo para França, Alemanha, Espanha e EUA. Como Alfredo González-Ruibal (2006) assinalou sobre os reassentamentos na Etiópia comunista, o sonho da razão produz ruínas. As casas dos engenheiros, abandonadas no Centro Administrativo, são o reflexo material do fracasso da colonização fascista interna. Assim como os centros cívicos da Terra Chá, mal sinalizados na estrada, em decadência e cheios de vegetação.

Uma arqueologia pós-colonial permitir-nos-á descolonizar estas materialidades, explicitar o carácter fascista dos regimes salazarista e franquista e propor narrativas e novos usos de um património crítico, por vezes traumático, outras vezes rejeitado, mas também naturalizado e branqueado através de histórias tecnocráticas que nos falam de produtividade, saneamento, higiene, progresso e luta do homem contra a natureza. Foi a partir do ponto de vista dos engenheiros fascistas que o comunal passou a ser concebido como um baldio subutilizado, improdutivo e insalubre. A Arqueologia é um know-how, uma técnica útil para o desenvolvimento sustentável destes espaços rurais. As colónias de que aqui falamos são autênticas paisagens arqueológicas fossilizadas (Cabana, 2008, p. 51) e têm enorme potencial para o que é conhecido como turismo de memória. Através das ruínas e da arquitetura podemos percorrer todo o século XX, elaborar sugestivas histórias sobre o Estado Novo, a $2^{\underline{a}}$ Guerra Mundial, a exploração do volfrâmio, o eletrofascismo e o fim do salazarismo e do franquismo. E tudo isto com a intenção de gerar recursos visitáveis, mas também para estimular o espírito crítico dos cidadãos quando se trata de lidar com os vestígios materiais das ditaduras ibéricas.

São doze e meia, num dia ensolarado de outono. Estamos na praça do centro social da colónia de A Boalhosa-Lamas-Vascões. Em frente a Mercúrio, e o indicador de Vénus, é uma das casas geminadas concebidas no início da década de 1950. Na entrada, uma idosa utiliza um chapéu largo de palha e está vestida com um luto rigoroso. Talvez seja uma das últimas sobreviventes da primeira geração de colonos. Está a rezar o terço e vira o olhar para a minúscula Nossa Senhora que encontra logo após Mercúrio, ao pé da moderna casa da professora (1958), hoje abandonada. A colónia agrícola parece um enorme henge do século XX, construído sobre as cinzas dos primeiros colonos neolíticos. Não há mais crianças. Apenas os fantasmas do passado, um centro de interpretação ambiental fechado e uma rota interplanetária. O Estado Novo foi capaz de gerar fenómenos reais poltergeist. 


\section{BIBLIOGRAFIA}

ALARES LÓPEZ, Gustavo (2010) - El vivero eterno de la esencia española. Colonización y discurso agrarista en la España de Franco. In ALCUTÉN SABIO, Alberto, ed.-Colonos, territorio y Estado. Los pueblos del agua de Bardenas. Zaragoza: Institución Fernando el Católico, pp. 57-8o.

ALMAGRO BASCH, Martín (1943) - La colaboración de la aviación española en el campo de la Arqueología. Ampurias. Barcelona. 5, pp. 247-249.

AYÁN VILA, Xurxo e SEÑORÁN MARTÍN, José Mํㅗ. (2015) - La vivienda como necesidad y deber de la justicia social. Por una Arqueología de los poblados obreros del noroeste. In ÁLVAREZ ARECES, Miguel Ángel, ed. - Vivienda obrera en la ciudad industrial del siglo XX. Madrid: TICCIH España, pp. 193-199.

BAPTISTA, F. Oliveira. (1993) - A política agrária do Estado Novo. Porto: Afrontamento.

BARRONES BUZÓN, Miguel A. (2012) - Colonización franquista: la cruzada interior. In Colonización y Memoria [http://www.magrama.gob.es/es/ministerio/archivos-bibliotecas-mediateca/mediateca/expo-memoria-colonizacion_tcm7-346691.pdf [Data de Consulta: 25/03/2015].

BAZÁN DE HUERTA, Moisés e LOZANO BARTOLOZZI, María del Mar (2015) - El Agro Pontino italiano y los pueblos de colonización en la provincia de Cáceres. Boletín del Seminario de Estudios de Arte y Arqueología. Valladolid. 31, pp. 203-229.

CABANA IGLESIAS, Ana (2008) - Lo que queda de las agras. La evolución del paisaje agrario en Galicia: A Terra Chá (1954-1968). Ager. Madrid. 7, pp. 33-56.

CAMPRUBÍ, Lino (2017) - Los ingenieros de Franco. Ciencia, catolicismo y Guerra Fría en el Estado franquista. Barcelona: Crítica.

CAPRESI, Vittoria (2019) - The Afterlife of Fascist Architecture and Town Planning. The Case of Itlaly's Pontine Plain and Colonial Lybia. In MELENHORST, Michel; POTTGIESSER, Uta; KELLNER, Theresa e JASCHKE, Franz, eds. - 100 Years Bauhaus. What interest do we take in Modern Movement Today? Berlín: Hochschule OWL. DOCOMOMO Deutschland, pp. 33-47.

CARVALHO, Rita Almeida de. (2018) - The Junta of Colonização Interna and the shaping of the Estado Novo's peasantry. In Regionalism, Nationalism and Architecture. Conference Proceedings (Porto, October 25-27, 2018): 54-62. Lisboa: Universidade de Lisboa, pp. 54-62.

CARDESÍN DÍAZ, José María (1987) - Política agraria y transformaciones en la agricultura gallega: la zona de colonización de Terra Chá (1954-1973). Agricultura y Sociedad. Madrid. 44, pp. 243-28o.

CASIMIRO, Tánia e SEQUEIRA, João, coords. (2020) - Arqueologia contemporânea em Portugal. Lisboa: Mazu press.
CENTELLAS SOLER, Miguel (2010) - Los pueblos de colonización de la administración franquista en la España Rural. $P+C$ : proyecto y ciudad, revista de temas de arquitectura, 1 , pp. 109-126.

COELHO, Rui G. e AYÁN VILA, Xurxo (2020) - Cambedo, 1946: "Carta do achamento de Portugal". Vestígios: Revista Latino-Americana de Arqueologia Histórica, 13(2), pp. $63-87$.

COSTA, Ana Mafalda Almeida Guimaraes. (2017) - Arquitectura agrícola. As Colónias do Estado Novo para o Barroso. Dissertação de Mestrado. Porto: Universidade Lusíada do Porto.

FERNÁNDEZ LAVANDERA, Odón e PIZARRO CHECA, Antonio (1980) - La transformación del brezal a la pradera en Galicia. Revista de Estudios Agrosociales, 110. pp. 61-82.

FLORES SOTO, José Antonio (2013) - La construcción del lugar. La plaza en los pueblos del Instituto Nacional de Colonización. Historia Agraria. Madrid. 6o, pp. 119-154.

FONSECA, Inês (2004) - A bem da nação! Modernização e resistência em meio rural durante o Estado Novo. In FREIRE, Dulce; FONSECA, Inês e GODINHO, Paula, coords. - Mundo Rural. Transformação e Resistência na Península Ibérica (Século XX). Lisboa: Colibri, pp. 71-85.

FREIRE, Dulce (2004) - Os baldios da discórdia: as comunidades locais e o Estado. In FREIRE, Dulce; FONSECA, Inês e GODINHO, Paula, coords. - Mundo Rural. Transformação e Resistência na Península Ibérica (Século XX). Lisboa: Colibri, pp. 191-224.

FREIRE, Dulce; FONSECA, Inês e GODINHO, Paula. (1998) - Soluções do Estado Novo. Educar o Barrosão no cultivo racional das suas terras. História. Lisboa. 6, pp. 34-41.

GONÇALVES, Vítor S. (2011) - Vere Gordon Childe em Portugal. Uma pequena história (moral?) sobre um joven lobo ainda inexperente e uma raposa matreira. O Arqueólogo Português. Lisboa. Série V, 1, pp.313-329.

GONÇALVES, Márcia (2018) - Of peasants and settlers: ideals of Portugueseness, imperial colonialism and European settlement in Africa, c. 1930-c. 1945. European Review of History: Revue Européenne d'Histoire, 25(1), pp. 166-186.

GONZÁLEZ RUIBAL, Alfredo (2006) - The Dream of Reason: An archaeology of the failures of modernity in Ethiopia. Journal of Social Archaeology, 6(2): 175-201.

GUERREIRO, Filipa de Castro. (2016) - Colónias Agrícolas Portuguesas Construídas pela Junta de Colonização Interna entre 1936 e 1960. A casa, o asentamento, o territorio. Tese de Doutoramento. Porto: Universidade do Porto.

NINHOS, Cláudia (2017) - Portugal e os nazis. Histórias e segredos de uma aliança. Lisboa: A Esfera dos Livros.

OLIVEIRA, Ana das Mercês (2018) - Colónias Agrárias da Junta de Colonização Interna no concelho de Montalegre - 
Modos de habitar a ruralidade. Dissertação de Mestrado. Porto: Facultade de Arquitectura da Universidade do Porto.

PÉREZ ESCOLANO, Víctor (2005) - Pueblos de colonización franquista: objetivo patrimonial. $\mathrm{PH}$ Boletín del Instituto Andaluz del Patrimonio Histórico. Sevilla. 52: 38-42.

RAPAZOTE, João (2012) - “Aldeias-Jardim” no concelho de Montalegre. O projeto da Junta de Colonização Interna para os baldios do Barroso. Revista de Geografia e Ordenamento do Território, 1, pp. 207-36.

ROSAS, Fernando (2001) - O salazarismo e o homem novo: Ensaio sobre o Estado Novo e a questão do totalitarismo. Análise Social, XXXV, 157, pp. 1031-1054.

ROSAS, Fernando. (2018) - Salazar e o Poder. A Arte de Saber Durar. Lisboa: Tinta-da-China.

ROSAS, Fernando. (2019) - Salazar e os Fascismos. Lisboa: Tinta-da-China.

SAMUELS, Joshua (2010) - Of Other Scapes: Archaeology , Landscape and Heterotopia in Fascist Italy. Archaeologies, 6(1), pp. 62-81.

SARAIBA, Tiago (2010) - Fascist Landscapes: Geneticists, Wheat, and the Landscapes of Fascism in Italy and Portugal. Historical Studies in the Natural Sciences, 40 (4), pp. 457-498.

SEÑORÁN MARTÍN, José Mª e AYÁN VILA, X. (2015) Los pueblos del agua. Colonización agraria y control social en la provincia de Cáceres durante la dictadura franquista. Arkeogazte. Vitoria-Gasteiz. 5, pp. 189-205.

SILVA, María Fátima Matos da (2006) - O povoamento pre-histórico e a romanização da bacia superior do rio Coura: estudo, musealização e divulgação. Tese de Doutoramento. Universidade de Granada.

SILVA, Maria Elisa Oliveira Silva da Lopes (2011) - A propriedade e os sujeitos: colonização interna e colónias agrícolas durante o Estado Novo. Dissertação de Mestrado, Universidade Nova de Lisboa.

STAMPACCHIA, Mauro (2000) - Ruralizzare l'Italia! Agricolture e bonifiche tra Mussolini e Serpieri (1928-1943). Milán: Franco Angeli.

TEJERIZO GARCÍA, Carlos e RODRÍGUEZ GUTIÉRREZ, Alejandro (2020) - Arqueología de la guerra después de la guerra. Vestígios. Revista Latino-Americana de Arqueología Histórica, 13 (2), pp. 9-35.

TORDESILLAS, Antonio A. e MEISS, Alberto (2013) - “El corazón de los pueblos de colonización”. Boletín académico. Revista de investigación y arquitectura contemporánea, 3, pp. 37-48.

VERACINI, Lorenzo (2018) - Italian Colonialism through a Settler Colonial Studies Lens. Journal of Colonialism and Colonial History, 19(3).
VILANOVA I VILA-ABADAL, Francesc (2014) - Bajo el signo de la esvástica. La Exposición de Arquitectura Moderna alemana en España (1942). Diacronie. Studi di Storia Contemporanea, 18(2).

ZAS GÓMEZ, Evaristo (2002) - A Terra Chá de Lugo, un caso atípico de poblado INC. In Actas del Congreso Arquitectura, ciudad e ideología antiurbana. Pamplona: Universidad de Navarra, pp. 197-203. 


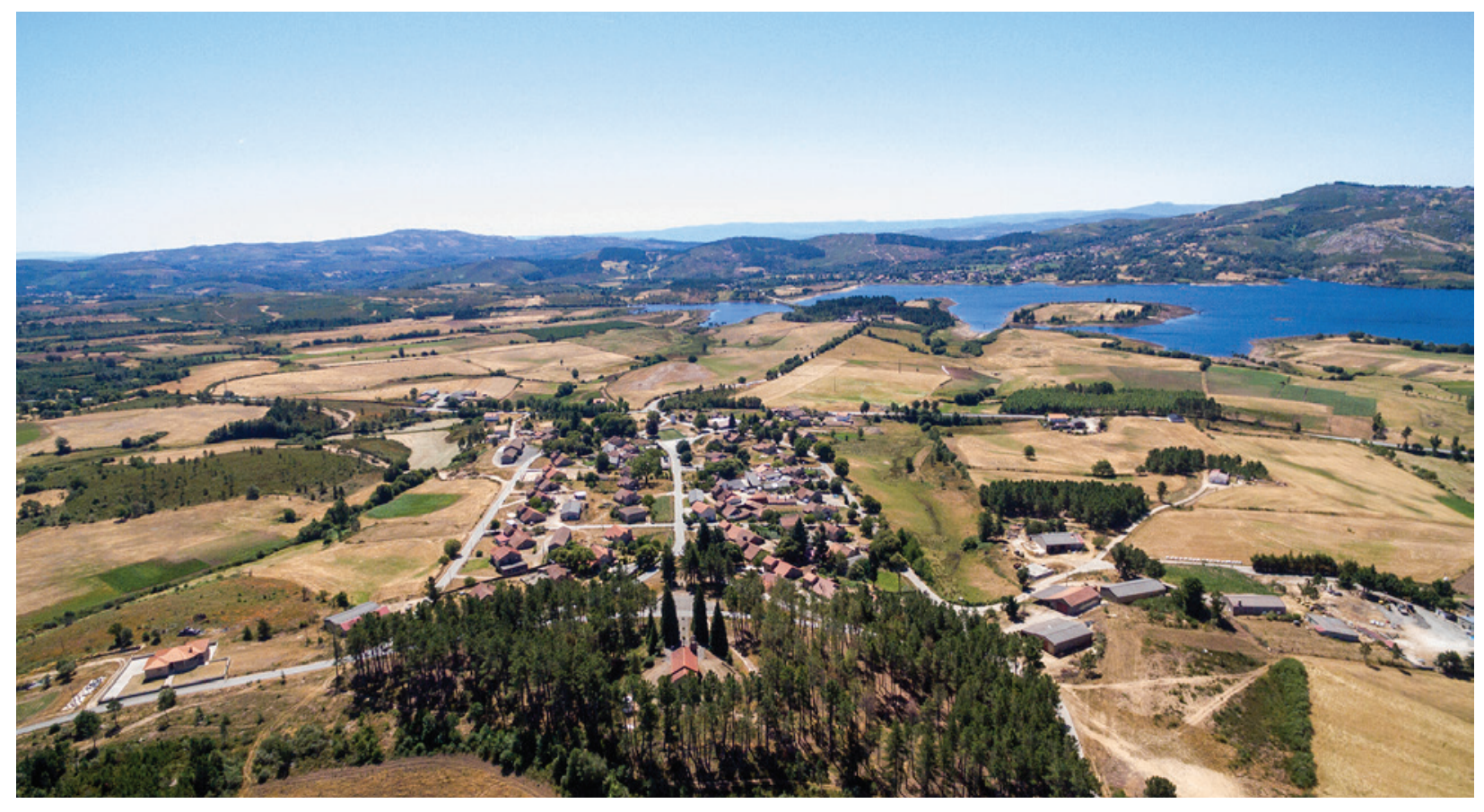

Figura 1-A colonia agrária de Aldeia Nova de Barroso (Montalegre) em julho de 2020 (ortofoto de Manoel A. Franco Fernández).

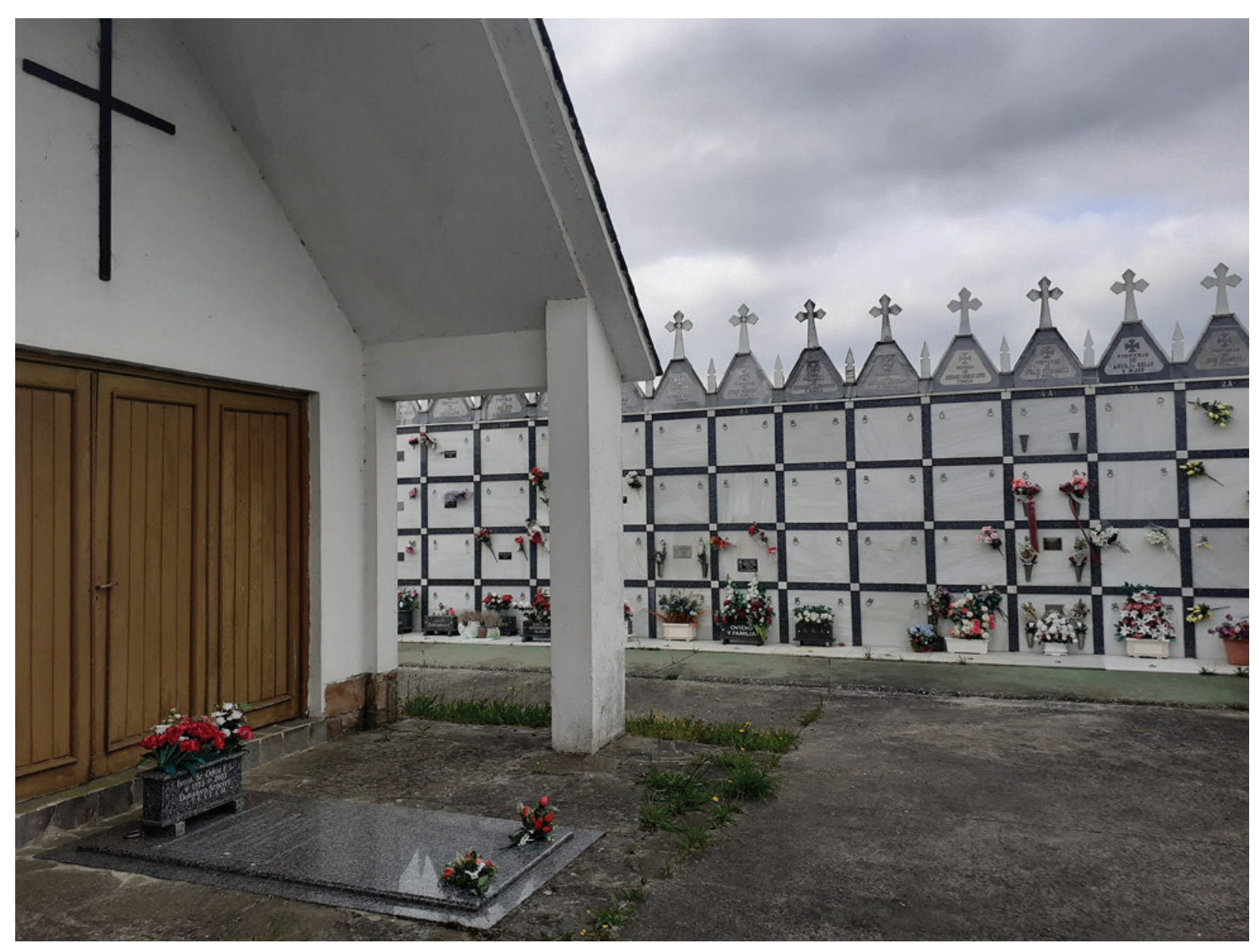

Figura 2 - Túmulo funerario do engenheiro Odón Fernández Lavandeira no cemitério vizinho do Centro Cívico do Arneiro. Junho de 2020 (foto de Xurxo Ayán). 



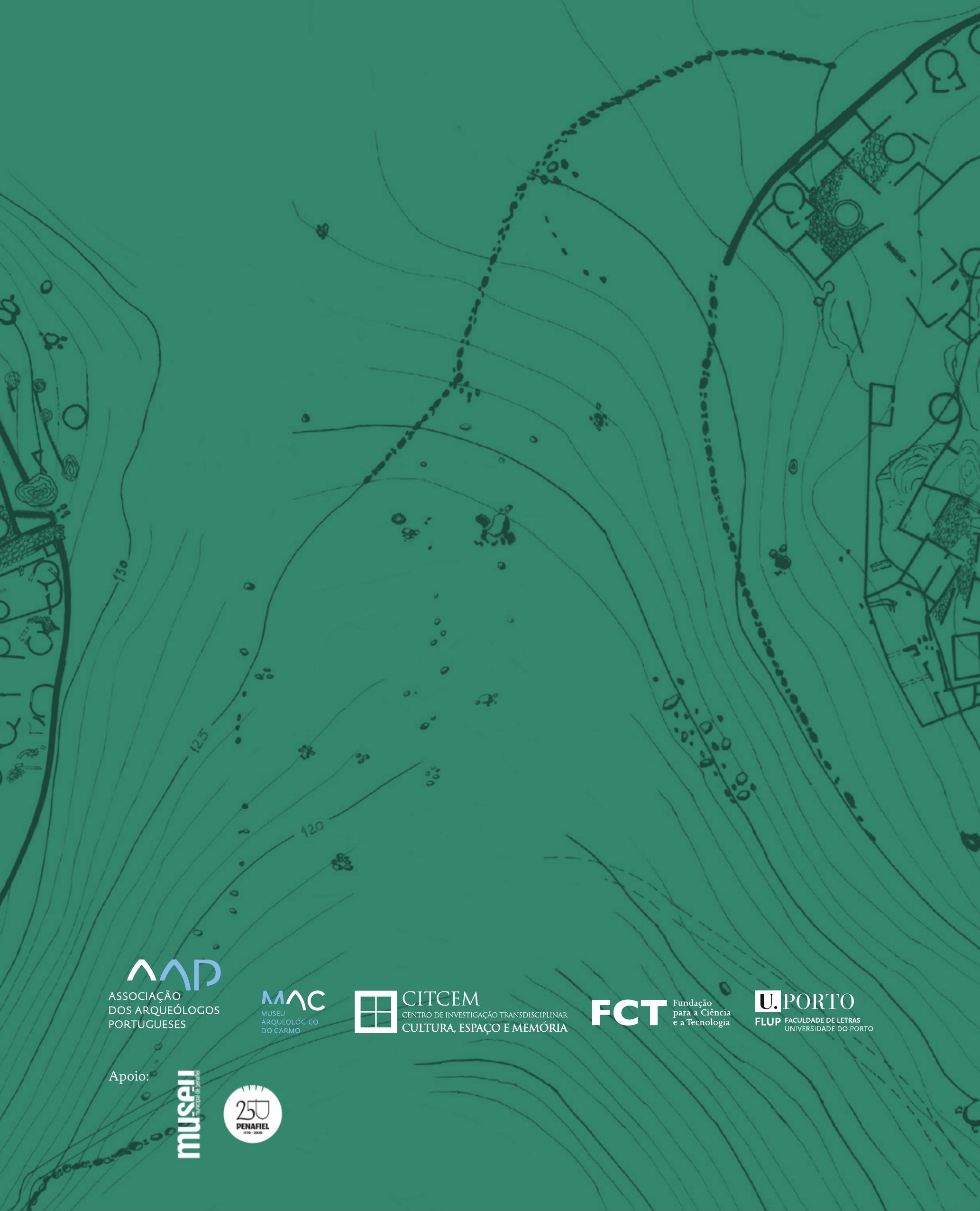

